\title{
Simultaneous determination of iron and copper in children's sera by FAAS
}

SVJETLANA LUTEROTTI ${ }^{1 *}$ TONČICA VUKMAN KORDIĆ ${ }^{2}$ SLAVICA DODIG ${ }^{3}$

${ }^{1}$ University of Zagreb, Faculty of Pharmacy and Biochemistry Zagreb, Croatia

${ }^{2}$ HALMED - Agency for Medicinal Products and Medical Devices Zagreb, Croatia

${ }^{3}$ Children's Hospital Srebrnjak Zagreb, Croatia

\begin{abstract}
A new and simple flame atomic-absorption spectrometric (FAAS) method is proposed for simultaneous determination of iron and copper in children's sera. It is based on single-step sample pretreatment (deproteinization with 3 mol L ${ }^{-1} \mathrm{HCl}$, ratio 1:1) and single-step calibration using $1.5 \mathrm{~mol} \mathrm{~L}^{-1} \mathrm{HCl}$ standard. During method's optimization a short multifactorial design experiment was used. The proposed method assures accuracy, sensitivity and precision comparable to that of the reference methods. The new approach is simple and time-, labour- and serum-saving, the latter being especially important in pediatric diagnostics.
\end{abstract}

Keywords: iron, copper, children's serum, FAAS, single-step determination

The analysis of metal ions in clinical materials is usually carried out by atomic absorption (FAAS/GFAAS), emission (ICP-AES) or mass spectrometry (ICP-MS). These standard techniques require elaborate and costly pretreatments of the samples.

In general, analytical instrumentation for clinical work is selected based upon the element(s) to be determined, the matrix (or matrices) to be analyzed, and the concentration(s) of the analytes expected in the clinical specimen. Laboratories specializing in a single application such as that for $\mathrm{Pb}$ in blood, serum $\mathrm{Al}$, or serum $\mathrm{Cu}$ and $\mathrm{Zn}$, are unlikely to make the switch to ICP-MS since such assays can be performed adequately using the existing AAS methods. However, if the application is biomonitoring for a panel of trace elements at background levels, then ICP-MS is the logical approach (1).

As long as 30 years ago, Weinstock and Uhlemann (2) proposed automated injection of microliter samples into FAAS for determination of copper in untreated, undiluted sera. At about the same time, Makino and Takahara $(3,4)$ proposed micromethods for determination of metal ions in infants' plasma by discrete nebulization in FAAS. They reported simple dilution with water for $\mathrm{Cu}$ and $\mathrm{Zn}(3)$, and treatment with TCA-ascorbate

\footnotetext{
*Correspondence; e-mail: sluter@pharma.hr
} 
solution for iron (4). Salmela and Vuori (5) proposed a simple and reliable FAAS method for measurement of $\mathrm{Cu}$ and $\mathrm{Zn}$ in serum diluted with water. The method was adoptable to pediatric research because of the small sample volume required. Terres-Martos et al. (6) proposed the FAAS method for determination of copper in human serum mineralized with an $\mathrm{HNO}_{3} / \mathrm{HClO}_{4}(4: 1)$ mixture and heated to $120{ }^{\circ} \mathrm{C}$ for 60 minutes in a mineralization block. Lopes et al. (7) described a fully automated flow system to accomplish sequential determination of copper in serum and urine by FAAS. Serum samples were diluted 2-fold with water and standard solutions were prepared with $20 \%$ glycerol. The developed flow system allowed multiple tasks to be carried out sequentially, such as preparation of serum samples (sample and standard solution viscosity adjustment), serum copper measurement, urine copper preconcentration and subsequent elution and measurement.

Despite the fact that different approaches are very well known, the reference methods still suggest assaying of twice diluted sera for iron and copper by flame atomicabsorption spectrometry, after deproteinization with $20 \%$ trichloroacetic acid (TCA) or simple dilution with water, resp. (8). It follows that introducing a new, simple and reliable assay method is still a challenging task.

Data on metal ion concentration in pediatric population sera might be used as a valuable biomarker of children's health status. The current research is a logical continuation of the authors' efforts to develop new reliable analytical procedures for quantitation of metal ions in human serum by FAAS (9). Whereas the former method has been devoted particularly to the analysis of sera with pathologically low copper levels, the main objective of the investigation presented here is to introduce a new approach aimed at simultaneous determination of Fe and $\mathrm{Cu}$ in children's sera. The latter is based on single-step sample pretreatment and single-step calibrant preparation.

\section{EXPERIMENTAL}

\section{Materials}

Standard solutions. - The concentration of stock standard solutions was 1026.81 $\mu \mathrm{g} \mathrm{mL} \mathrm{m}^{-1}$ for copper and $9917.49 \mu \mathrm{g} \mathrm{mL}^{-1}$ for iron. Copper stock solution was prepared by dissolving $\mathrm{CuCl}_{2} \times 2 \mathrm{H}_{2} \mathrm{O}$ in $0.1 \mathrm{~mol} \mathrm{~L}^{-1} \mathrm{HCl}$. Iron stock solution was purchased from SCP Science, Canada. Both stock solutions were standardized complexometrically.

To obtain working standard solutions for calibration $(0.2,0.4,0.6,0.8,1.0,1.2,1.6$ and $2.0 \mu \mathrm{g} \mathrm{mL}^{-1}$ analyte), stock solutions were serially diluted with different diluents: $10 \%$ TCA, $10 \%$ glycerol, $1.5 \mathrm{~mol} \mathrm{~L}^{-1} \mathrm{HCl}, \mathrm{HCl}$-acidified synthetic serum. For standard additions (0.3, 0.5, 0.7, 1.0, 1.5 and $2.0 \mu \mathrm{g} \mathrm{mL}^{-1}$ analyte), $\mathrm{HCl}$-acidified serum pool was used.

Reagents. - Ultrapure water (electrolytic conductivity $0.055 \mu \mathrm{S} \mathrm{cm}^{-1}$ ) was used throughout. Trichloroacetic acid (Kemika, Croatia), hydrochloric acid 35 \% (Lach-Ner, Czech Republic) and glycerol (Gram-mol, Croatia), $\mathrm{NaHCO}_{3}$ (Kemika), $\mathrm{KCl}$ (Lach-Ner), $\mathrm{MgCl}_{2}$ $\times 6 \mathrm{H}_{2} \mathrm{O}$ (Kemika), $\mathrm{Na}_{2} \mathrm{HPO}_{4} \times 2 \mathrm{H}_{2} \mathrm{O}$ (Merck, Germany), $\mathrm{CaCl}_{2} \times 2 \mathrm{H}_{2} \mathrm{O}$ (Merck Alkaloid, Macedonia) and $\mathrm{NaCl}$ (Zorka, Serbia) were all of pro analysi grade. 
Serum pool. - The pool of children's sera was obtained from the Children's Hospital Srebrnjak, Zagreb, Croatia, in 2006 and 2007, and was stored at $-20{ }^{\circ} \mathrm{C}$. All the experiments were approved by the Ethical Committee of the Children's Hospital Srebrnjak, Zagreb, Croatia.

$\mathrm{HCl}$-acidified serum pool was prepared by using the serum pool and $3 \mathrm{~mol} \mathrm{~L}^{-1} \mathrm{HCl}$ at an equivolume ratio.

Synthetic serum (real blank). - Synthetic serum was prepared by dilution of human albumin $20 \%$ or intravenous immunoglobulin (both from the Institute of Immunology, Zagreb, Croatia), $\mathrm{NaHCO}_{3}, \mathrm{Na}_{2} \mathrm{HPO}_{4} \times 2 \mathrm{H}_{2} \mathrm{O}, \mathrm{KCl}, \mathrm{MgCl}_{2} \times 6 \mathrm{H}_{2} \mathrm{O}, \mathrm{CaCl}_{2} \times 2 \mathrm{H}_{2} \mathrm{O}$ and $\mathrm{NaCl}$ in ultrapure water.

$\mathrm{HCl}$-acidified synthetic serum was prepared by using synthetic serum and $3 \mathrm{~mol} \mathrm{~L}^{-1}$ $\mathrm{HCl}$ at an equivolume ratio.

\section{Equipment}

The FAAS instrument used was a PerkinElmer (USA) AAnalyst 800 atomic absorption spectrometer with deuterium background corrector (DBC).

To centrifuge the samples, a microcentrifuge Eppendorf 5415D (Eppendorf, Germany) was used.

\section{Analytical procedures}

Determination of $\mathrm{Cu}$ in serum by the reference method (8). - Sample (serum pool) was diluted 2-fold with ultrapure water, homogenized and let settle, and then aspirated directly into the nebulizer system of the instrument. Copper concentration was determined by comparison with standard solutions prepared in $10 \%$ glycerol (see under Standard solutions). Instrumental parameters are given in Table I.

Determination of Fe in serum by the reference method (8). - The sample was diluted 1:1 with TCA $20 \%$, stirred and heated at $90{ }^{\circ} \mathrm{C}$ for 15 minutes in a water bath. After cooling it was centrifuged, supernatant was decanted and aspirated directly into the nebulizer

Table I. Instrumental parameters

\begin{tabular}{lcc}
\hline Element & $\mathrm{Cu}$ & $\mathrm{Fe}$ \\
\hline Lamp type & $\mathrm{HCL}^{\mathrm{a}}$ & $\mathrm{HCL}^{\mathrm{a}}$ \\
Lamp current $(\mathrm{mA})$ & 15 & 30 \\
Wavelength $(\mathrm{nm})$ & 324.8 & 248.3 \\
Fuel/oxidant & acetylene/air & acetylene $/$ air \\
Acetylene pressure $(\mathrm{Pa}) /$ flow rate $\left(\mathrm{L} \mathrm{min}^{-1}\right)$ & $0.9 \times 10^{5} / 2$ & $0.9 \times 10^{5} / 2$ \\
Air pressure $(\mathrm{Pa}) /$ flow rate $\left(\mathrm{L} \mathrm{min}^{-1}\right)$ & $5.5 \times 10^{5} / 17$ & $5.5 \times 10^{5} / 17$ \\
Slit setting $(\mathrm{nm})$ & 0.7 & 0.2 \\
\hline
\end{tabular}

a Hollow cathode lamp. 
system of the instrument. Iron concentration was determined by comparison with a series of standard solutions which were prepared in $10 \%$ TCA (see under Standard solutions). For instrumental parameters see Table I.

Optimization of the new method. - In the course of the new method optimization, copper and iron concentrations in serum pool were determined after varying the following parameters: concentration of $\mathrm{HCl}$ for deproteinization, time of sample settling and stirring, storage temperature, speed and time of centrifuging (see Table II).

$3 \mathrm{~mol} \mathrm{~L}^{-1}$ was found to be the optimum concentration of $\mathrm{HCl}$. Systems using 2 and $5 \mathrm{~mol} \mathrm{~L}-1 \mathrm{HCl}$ were found unstable. After centrifugation of samples diluted 2-fold with $2 \mathrm{~mol} \mathrm{~L}^{-1} \mathrm{HCl}$, the supernatant was always turbid while the measured absorbance for systems using $5 \mathrm{~mol} \mathrm{~L}^{-1} \mathrm{HCl}$ was always too high in respect to other systems. The latter might indicate a possible chemical interference.

The temperature chosen for samples storage before centrifuging was $50{ }^{\circ} \mathrm{C}$; samples stored at room temperature $\left(25^{\circ} \mathrm{C}\right)$ were opalescent and the ones stored at $90^{\circ} \mathrm{C}$ showed problems when decanting supernatant from the sediment. Therefore, efficient deproteinization of serum sample with $3 \mathrm{~mol} \mathrm{~L}^{-1} \mathrm{HCl}$ at elevated temperature $\left(t=50{ }^{\circ} \mathrm{C}\right)$ is suggested for both analytes.

Stirring time of five minutes and settling time of 5 minutes at $50{ }^{\circ} \mathrm{C}$ were sufficient to get clear and stable supernatants ready to measure. Centrifuging time had to be prolonged from 5 to 10 minutes; it was otherwise impossible to decant supernatant from the sediment of the $\mathrm{HCl}$-synthetic serum samples.

No differences were observed between samples regardless of the centrifugation speed (15000 or $20000 g$ ).

Table II. Optimization of working parameters

\begin{tabular}{lcc}
\hline Parameter & Parameter values tested & Optimized parameter \\
\hline $\mathrm{HCl}$ concentration $\left(\mathrm{mol} \mathrm{L}^{-1}\right)$ & $2,3,5$ & 3 \\
Stirring time $(\mathrm{min})$ & $5,15,30$ & 5 \\
Settling time before centrifuging $(\mathrm{min})$ & $5,15,30$ & 5 \\
Temperature $\left({ }^{\circ} \mathrm{C}\right)$ & $25,50,90$ & 50 \\
Centrifuging time $(\mathrm{min})$ & $5,10,15$ & 10 \\
Centrifuging speed $(\mathrm{g})$ & 15000,20000 & 15000 \\
\hline
\end{tabular}

Simultaneous determination of $\mathrm{Cu}$ and Fe by the proposed method. - To avoid any contamination of samples and standard solutions, laboratory glassware and plasticware were soaked in nitric acid 1:1 for $24 \mathrm{~h}$ and then rinsed several times with ultrapure water.

Copper and iron stock solutions were added to $1.5 \mathrm{~mol} \mathrm{~L}{ }^{-1} \mathrm{HCl}$ or $\mathrm{HCl}$-acidified synthetic serum, both for calibration, or to $\mathrm{HCl}$-acidified serum pool for standard additions (see under Standard solutions). Working standard solutions were prepared fresh daily.

After allowing it to equilibrate to room temperature, the serum pool sample was stirred for 10 minutes on a magnetic stirrer. It was then diluted 1:1 with $3 \mathrm{~mol} \mathrm{~L}^{-1} \mathrm{HCl}$, mixed for 5 minutes on the shaker and heated at $50{ }^{\circ} \mathrm{C}$ for 5 minutes in a water bath. Af- 
ter cooling, it was centrifuged for 10 minutes at $15000 \mathrm{~g}$, the supernatant was decanted and aspirated directly into the nebulizer system of the instrument. Copper and iron concentrations were evaluated from the calibration line. For instrumental parameters see Table I.

Statistical analysis. - The data obtained for the reference methods and the proposed method and the data obtained by different calibration approaches were statistically compared on the basis of: (i) calibration sensitivity (CS), namely, the slope of the calibration line, or (ii) estimated analyte concentration. Student's $t$-test was used.

Robustness of the proposed method was also examined by short multifactorial design (SMD) experiments based on Youden and Steiner's and Plackett and Burman's design (10-14). Since robustness is the measure of a method's capacity to remain unaffected by small but deliberate variations in internal parameters of the method, it provides indication of the method's reliability during normal usage. In our case, 7 parameters were tested through 8 experiments. The basis of testing was the analysis of iron. The experimental design is presented in Table III and each of the 7 parameters was changed between two levels (namely A/a through G/g).

Table III. Short multifactorial design

\begin{tabular}{|c|c|c|c|c|c|c|c|c|}
\hline \multirow{2}{*}{$\begin{array}{l}\text { Variable } \\
\text { factor }\end{array}$} & \multicolumn{8}{|c|}{ Experiment } \\
\hline & 1 & 2 & 3 & 4 & 5 & 6 & 7 & 8 \\
\hline $\mathrm{A} / \mathrm{a}$ & A & A & A & $\mathrm{a}$ & A & $\mathrm{a}$ & $\mathrm{a}$ & A \\
\hline $\mathrm{B} / \mathrm{b}$ & B & B & $\mathrm{b}$ & $\mathrm{b}$ & B & $\mathrm{b}$ & B & $\mathrm{b}$ \\
\hline $\mathrm{C} / \mathrm{c}$ & C & C & C & c & c & C & c & c \\
\hline $\mathrm{D} / \mathrm{d}$ & $\mathrm{D}$ & d & d & d & $\mathrm{D}$ & $\mathrm{D}$ & d & D \\
\hline $\mathrm{E} / \mathrm{e}$ & $\mathrm{E}$ & e & $\mathrm{E}$ & E & E & e & e & e \\
\hline$F / f$ & $\mathrm{~F}$ & $\mathrm{~F}$ & $\mathrm{f}$ & $\mathrm{F}$ & $\mathrm{F}$ & $\mathrm{F}$ & $\mathrm{f}$ & $\mathrm{f}$ \\
\hline $\mathrm{G} / \mathrm{g}$ & G & g & G & g & G & G & G & $\mathrm{g}$ \\
\hline
\end{tabular}

Variable factors: $\mathrm{HCl}$ conc.: A $\left(2 \mathrm{~mol} \mathrm{~L}^{-1}\right) / \mathrm{a}\left(3 \mathrm{~mol} \mathrm{~L}^{-1}\right)$; stirring time: $\mathrm{B}(5 \mathrm{~min}) / \mathrm{b}(15 \mathrm{~min})$; settling time before centrifuging: $\mathrm{C}(5 \mathrm{~min}) / \mathrm{c}(15 \mathrm{~min})$; temperature: $\mathrm{D}$ (room temperature)/d $\left(50{ }^{\circ} \mathrm{C}\right)$; centrifuging time: $\mathrm{E}(10$ $\mathrm{min}) / \mathrm{e}(15 \mathrm{~min})$; centrifuging speed: F $(15000 \mathrm{~g}) / \mathrm{f}(20000 \mathrm{~g})$; settling time before signal measurement: G (15 $\mathrm{min}) / \mathrm{g}(30 \mathrm{~min})$.

\section{RESULTS AND DISCUSSION}

\section{Trueness of the new method}

In the development of the new method, statistical comparison of the new approach with the reference methods (8), for both analytes, was performed at $P=95 \%$, in regard to sample pretreatment and in regard to various calibration approaches. Calibration approaches examined were: (i) standard additions, (ii) calibration in HCl-acidified synthetic serum and (iii) calibration in $\mathrm{HCl}$. Data analysis was based on the analyte concentration and calibration sensitivity results. 
Table IV. Estimated concentrations for $\mathrm{Fe}$ and $\mathrm{Cu}$ in serum pool

\begin{tabular}{llcccc}
\hline & \multicolumn{2}{c}{ Fe } & \multicolumn{2}{c}{$\mathrm{Cu}$} \\
\cline { 3 - 6 } & & $\left.\gamma(\mu \mathrm{g} \mathrm{mL})^{-1}\right)^{\mathrm{a}}$ & $\begin{array}{c}\text { RSD } \\
(\%) / N\end{array}$ & $\gamma\left(\mu \mathrm{g} \mathrm{mL}^{-1}\right)^{\mathrm{a}}$ & $\begin{array}{c}\text { RSD } \\
(\%) / N\end{array}$ \\
\hline \multirow{2}{*}{$\begin{array}{l}\text { Proposed } \\
\text { method }\end{array}$} & Calibration in 1.5 mol L ${ }^{-1} \mathrm{HCl}$ & $0.991 \pm 0.097$ & $9.8 / 23^{\mathrm{e}}$ & $1.283 \pm 0.022^{\mathrm{b}}$ & $1.7 / 3^{\mathrm{f}}$ \\
& Calibration in ASM/2 & $0.981 \pm 0.097$ & $9.9 / 9^{\mathrm{e}}$ & $1.102 \pm 0.113^{\mathrm{b}, \mathrm{c}, \mathrm{d}}$ & $10.3 / 9^{\mathrm{e}}$ \\
Reference & Calibration in 10\% TCA (Fe) & $0.969 \pm 0.103$ & $10.7 / 14^{\mathrm{e}}$ & - & - \\
methods & Calibration in 10\% glycerol (Cu) & - & - & $1.326 \pm 0.124^{\mathrm{c}}$ & $9.4 / 9^{\mathrm{e}}$ \\
\hline
\end{tabular}

ASM - HCl-acidified synthetic serum; $\gamma$ - estimated analyte concentration; $N$ - total number of points;

TCA - trichloroacetic acid

a Mean \pm SD.

Statistically significant difference at $P=95 \%$ : ${ }^{\mathrm{b}} t=2.6594\left(t_{\mathrm{tab}}=2.0595\right),{ }^{\mathrm{c}} t=4.0832\left(t_{\mathrm{tab}}=1.9905\right)$,

d $t=2.6222\left(t_{\mathrm{tab}}=2.0322\right)$.

e Intermediate precision.

${ }^{\mathrm{f}}$ Repeatability.

Estimated concentrations. - Data on estimated copper and iron concentrations and statistical inference are presented in Table IV.

All the concentration values lie within the reference intervals for copper and iron in pediatric population sera from Zagreb, Croatia (15).

Statistical analysis showed that the estimated concentration as proposed by the reference methods for iron (in $10 \%$ TCA) did not significantly differ from either standard additions to $\mathrm{HCl}$-acidified serum or calibration in $\mathrm{HCl}$-acidified real blank or calibration in $1.5 \mathrm{~mol} \mathrm{~L}^{-1} \mathrm{HCl}$. For copper, the estimated concentration as proposed by the reference method (in $10 \%$ glycerol) did not significantly differ from standard additions to $\mathrm{HCl}$ -acidified serum or calibration in $1.5 \mathrm{~mol} \mathrm{~L}^{-1} \mathrm{HCl}$ but it was found significantly different from calibration in $\mathrm{HCl}$-acidified real blank.

Calibration sensitivity and detection limit. - The observed effects on calibration sensitivity for both analytes are presented using collective calibration data (Table V).

Regarding both iron and copper, coefficients of correlation $(R>0.990)$ and residual sums of the squares indicate favourable linear correlations in all cases. Precision of slopes was good, with $\mathrm{RSD}_{\mathrm{CS}}$ values of $0.9-2.1$ and $0.6-1.8 \%$, respectively.

However, the slope of the calibration line for Fe in $10 \%$ TCA was found significantly different from calibration in $1.5 \mathrm{~mol} \mathrm{~L}^{-1} \mathrm{HCl}$ at $P=95 \%$. The latter was also significantly different from calibration in real blank and from standard additions. The slope of the calibration line for $\mathrm{Cu}$ in $10 \%$ glycerol was not found significantly different from calibration in $1.5 \mathrm{~mol} \mathrm{~L}^{-1} \mathrm{HCl}$. However, calibrations in $1.5 \mathrm{~mol} \mathrm{~L}^{-1} \mathrm{HCl}$ and $10 \%$ glycerol significantly differed from that in $\mathrm{HCl}$-synthetic serum and from standard additions at $P=95 \%$.

The results obtained through concentrations and through CS differ to some extent. Due to the fact that calibration sensitivity is prone to variability, our final conclusions were based on the estimated concentrations of the analytes (see Table IV). Here, the reference methods for both iron (in $10 \%$ TCA) and copper (in $10 \%$ glycerol) did not signifi- 
Table V. Calibration sensitivity for $\mathrm{Fe}$ and $\mathrm{Cu}^{a}$

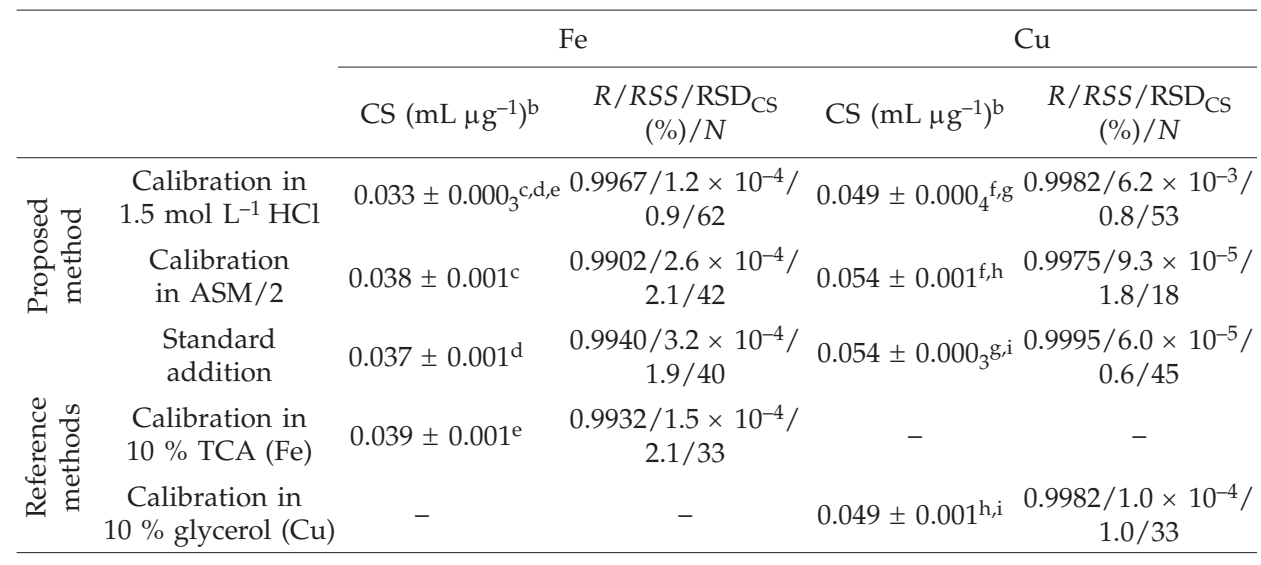

ASM - HCl-acidified synthetic serum; CS - calibration sensitivity, slope of the calibration line; $N$ - total number of points; $R$ - coefficient of correlation; RSS - residual sum of the squares; TCA - trichloroacetic acid a Non-ideal lines.

$\mathrm{b}$ Mean \pm SD.

Statistically significant difference at $P=95 \%:{ }^{\mathrm{c}} t=6.519\left(t_{\mathrm{tab}}=1.984\right) ;{ }^{\mathrm{d}} t=4.533\left(t_{\mathrm{tab}}=1.992\right) ;{ }^{\mathrm{e}} t=8.472$ $\left(t_{\mathrm{tab}}=1.986\right) ;{ }^{\mathrm{f}} t=5.952\left(t_{\mathrm{tab}}=1.996\right) ; \mathrm{g} t=10.175\left(t_{\mathrm{tab}}=1.986\right), \mathrm{h} t=4.943\left(t_{\mathrm{tab}}=2.012\right),{ }^{\mathrm{i}} t=8.592\left(t_{\mathrm{tab}}=\right.$ 1.993).

cantly differ from either standard additions to $\mathrm{HCl}$-acidified serum or calibration in 1.5 mol L ${ }^{-1} \mathrm{HCl}$. Accordingly, the latter two approaches might reliably replace both reference calibration media.

Detection limiting values $\left(D L=\frac{3.3 \times \mathrm{SD}_{\mathrm{i}}}{\mathrm{CS}}\right.$, where $\mathrm{SD}_{\mathrm{i}}$ equals standard deviation of the calibration line intercept) were estimated as $0.04 \mu \mathrm{g} \mathrm{mL}^{-1} \mathrm{Fe}$ and $0.03 \mu \mathrm{g} \mathrm{mL}^{-1} \mathrm{Cu}$.

Table VI. Ranked effects

\begin{tabular}{ccc}
\hline Factor & Ranked effect $\left(D_{\mathrm{i}}\right)$ & M value \\
\hline $\mathrm{G} / \mathrm{g}$ & -0.00175 & -1.35 \\
$\mathrm{~B} / \mathrm{b}$ & -0.00075 & -0.76 \\
$\mathrm{E} / \mathrm{e}$ & -0.00025 & -0.35 \\
$\mathrm{C} / \mathrm{c}$ & 0.00025 & 0 \\
$\mathrm{D} / \mathrm{d}$ & 0.00075 & +0.35 \\
$\mathrm{~A} / \mathrm{a}$ & 0.00075 & +0.76 \\
$\mathrm{~F} / \mathrm{f}$ & 0.00175 & +1.35 \\
\hline
\end{tabular}

$\sqrt{2} \cdot \sigma^{\prime}=0.00213$ 


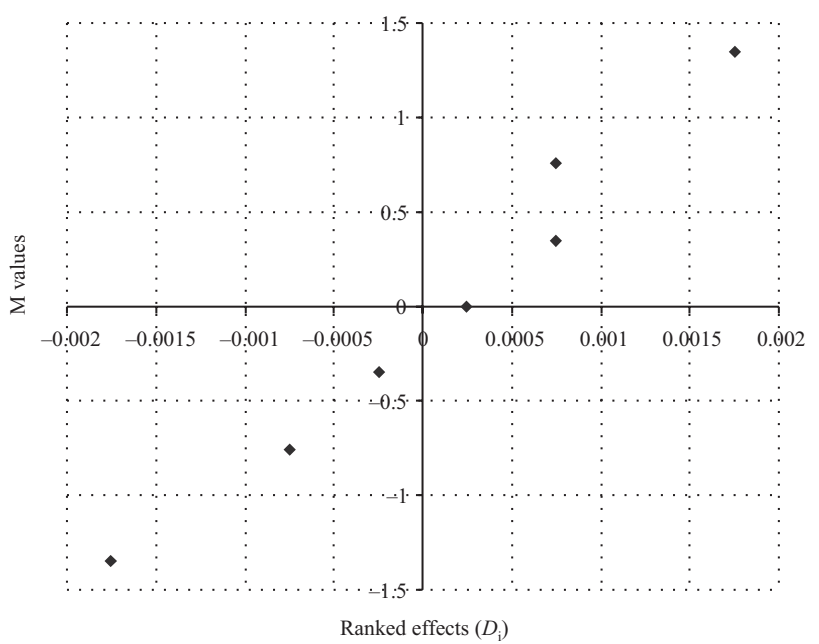

Fig. 1. Normal probability plot of the effects.

$S M D$. - The newly suggested treatment of samples prior to the analysis of iron was investigated by simultaneously varying 7 parameters at a time. The results of short multifactorial design experiments showed that a system is robust enough in regard to small but deliberate variations of basic working parameters such as concentration of $\mathrm{HCl}$ for deproteinization, temperature, speed and time of centrifuging, time of sample settling and stirring (see also Table II). From the results of eight experiments, the effect of each factor was calculated. Ranking of observed effects is presented in Table VI as well as the normal probability plot of effects in Fig. 1.

Factor effects $\left(D_{\mathrm{i}}\right)$ are calculated $(11,12)$ for each parameter by attaching the signs to the data collected, adding, and dividing by half the number of experiments. According to Fisher (11), the standard deviation of the eight individual results $\sigma^{\prime}$ equals to:

$$
\sigma^{\prime}=\sqrt{\frac{2}{7} \sum_{\mathrm{i}=\mathrm{a}}^{\mathrm{g}}\left(D_{\mathrm{i}}\right)^{2}}=1.5052 \times 10^{-3}
$$

and any value of $D_{\text {i }}$ can be considered significant $(p<0.05)$ if $|D|>\sqrt{2} \sigma$ '. As evident from Table VI, all the calculated factor effects were lower than the limiting value of 0.00213 and were not found to be significant. Accordingly, they are a normally distributed random noise and form a nearly straight line (see Fig. 1), suggesting that the method is rugged for the factors tested.

\section{Sensitivity and precision}

As evident from Table V, comparable calibration sensitivity is achieved by the reference and new methods: collective CS value (mean \pm SD, number of points $N$ ) for copper as obtained by the reference method was $0.049 \pm 0.001 \mathrm{~mL} \mathrm{\mu g}^{-1}(N=33)$ and $0.049 \pm 0.000_{4} \mathrm{~mL} \mathrm{\mu g}^{-1}(N=53)$ for the new method. Analogously, in case of iron, it was 
Table VII. Precision for iron and copper concentration estimates

\begin{tabular}{ccccc}
\hline \multirow{2}{*}{ Method } & \multicolumn{3}{c}{$\mathrm{Cu}$} & \multicolumn{2}{c}{$\mathrm{Fe}$} \\
\cline { 2 - 5 } & Repeatability & Intermediate precision & Repeatability & Intermediate precision \\
\cline { 2 - 5 } & RSD $(\%)$ & RSD $(\%)$ & RSD $(\%)$ & RSD $(\%)$ \\
\hline 1.5 mol L$^{-1} \mathrm{HCl}$ & 1.7 & $1.4-6.8$ & $0.0-16.1$ & 9.8 \\
Reference method & $0.0-10.7$ & 9.4 & $0.0-12.4$ & 10.7 \\
\hline
\end{tabular}

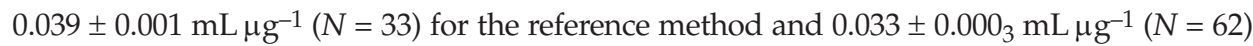
for the new method. Estimated concentration data was obtained with comparable precision for both the reference and new methods (see Tables IV and VII) and for both analytes. Other approaches showed comparable CS and precision values as well (Table V).

\section{CONCLUSIONS}

In conclusion, the new method for simultaneous determination of iron and copper in children's sera proposes one-step sample pretreatment (deproteinization with $3 \mathrm{~mol} \mathrm{~L}^{-1}$ $\mathrm{HCl}$, ratio 1:1) and one-step calibration using $1.5 \mathrm{~mol} \mathrm{~L}^{-1} \mathrm{HCl}$ standard for both analytes. Moreover, the proposed method assures sensitivity and precision comparable to that of the reference methods. According to all the above given arguments and in comparison with the already reported method for copper (9), which was particularly convenient for analyses of hypocupric adult sera, we are inclined to believe that the new approach reported here might be successfully applied for assaying both iron and copper in children's sera, with expected concentrations of $0.6-1.7 \mu \mathrm{g} \mathrm{mL}^{-1} \mathrm{Cu}$ and $0.2-1.8 \mu \mathrm{g} \mathrm{mL}^{-1} \mathrm{Fe}(15,16)$. The new method is simple and time-, labour- and serum-saving, the latter being especially important when pediatric patients are concerned.

\section{REFERENCES}

1. P. J. Parsons and F. Barbosa, Jr., Atomic spectrometry and trends in clinical laboratory medicine, Spectrochim. Acta Part B: At. Spectr. 62 (2007) 992-1003; DOI: 10.1016/j.sab.2007.03.007.

2. N. Weinstock and M. Uhlemann, Automated determination of copper in undiluted serum by atomic-absorption spectroscopy, Clin. Chem. 27 (1981) 1438-1440.

3. T. Makino and K. Takahara, Direct determination of plasma copper and zinc in infants by atomic absorption with discrete nebulization, Clin. Chem. 27 (1981) 1445-1447.

4. T. Makino and K. Takahara, Reference values: Accurate determination of plasma iron in infants by discrete nebulization in atomic absorption, Clin. Chem. 27 (1981) 2073.

5. S. Salmela and E. Vuori, Improved direct determination of copper and zinc in a single serum dilution by atomic absorption spectrophotometry, At. Spectrosc. 5 (1984) 146-149.

6. C. Terrés-Martos, M. Navarro-Alarcón, F. Martín-Lagos, H. L. G. de la Serrana and M. C. López-Martínez, Determination of copper levels in serum of healthy subjects by atomic absorption spectrometry, Sci. Total Environ. 198 (1997) 97-103; DOI: 10.1016/S0048-9697(97)05448-X. 
7. C. M. P. V. Lopes, A. A. Almeida, J. L. M. Santos and J. L. F. C. Lima, Automatic flow system for the sequential determination of copper in serum and urine by flame atomic absorption spectrometry, Anal. Chim. Acta 555 (2006) 370-376; DOI: 10.1016/j.aca.2005.09.013.

8. Analytical Methods for Atomic Absorption Spectrometry, PerkinElmer Bodenseewerk, Überlingen, Germany, August 2000, pp. 157, 160.

9. S. Luterotti and T. Vukman, Acidic method for determination of copper in blood serum by FAAS, Acta Pharm. 52 (2002) 143-148.

10. R. L. Plackett and J. P. Burman, The design of optimum multifactorial experiments, Biometrika 33 (1946) 305-325; DOI: 10.1093/biomet/33.4.305.

11. W. J. Youden and E. H. Steiner, Statistical Manual of the Association of Official Analytical Chemists, Association of Official Analytical Chemists, Washington (DC) 1975.

12. B. V. Fisher, Statistics in chemistry - collaborative trials, Anal. Proc. 21 (1984) 443-448; DOI: 10.1039/ ap9842100443.

13. L. D. Torbeck, Assay validation: Ruggedness and robustness with designed experiments, Pharm. Technol. 20 (1996) 169-172.

14. L. D. Torbeck and R. C. Branning, Designed experiments - A vital role in validation, Pharm. Technol. 20 (1996) 108-114.

15. Z. Flegar-Meštrić, N. Jagarinec, B. Šurina, D. Vrhovski-Hebrang, V. Preden-Kereković, S. Perkov and B. Smuđ-Makalouš, Reference intervals for biochemistry analytes determined in the sera of children and adolescents from Zagreb, Croatia, Biochem. Med. 6 (1996) 277-288.

16. G. Lockitch, A. C. Halstead, L. Wadsworth, G. Quigley, L. Reston and B. Jacobson, Age- and sex-specific pediatric reference intervals and correlations for zinc, copper, selenium, iron, vitamins A and E, and related proteins, Clin. Chem. 34 (1988) 1625-1628.

\section{$S A \check{Z} E T A K$}

\section{Simultano određivanje željeza i bakra u serumu djece FAAS-om}

SVJETLANA LUTEROTTI, TONČICA VUKMAN KORDIĆ i SLAVICA DODIG

Predložena je nova jednostavna metoda plamene atomsko-apsorpcijske spektrometrije (FAAS), za simultano određivanje željeza i bakra u serumu djece. Ona se temelji na predobradbi uzorka u jednom koraku (deproteinizacija s $3 \mathrm{~mol} \mathrm{~L}^{-1} \mathrm{HCl}$ u odnosu 1:1) i kalibraciji u jednom koraku sa standardom pripravljenim u $1.5 \mathrm{~mol} \mathrm{~L}-1 \mathrm{HCl}$. Tijekom optimizacije metode primijenjen je multifaktorski dizajnirani eksperiment. Preporučena metoda osigurava ispravnost, osjetljivost i preciznost usporedljivu onima referentnih metoda. Novi je pristup jednostavan i brz; on štedi i vrijeme i reagense i uzorke, pri čemu je potonje posebno važno u dječjoj dijagnostici.

Ključne riječi: željezo, bakar, dječji serum, FAAS, određivanje u jednom koraku

Sveučilište u Zagrebu, Farmaceutsko-biokemijski fakultet, Zagreb

Hrvatska agencija za lijekove i medicinske proizvode, Zagreb

Dječja bolnica Srebrnjak, Zagreb 